\title{
Ethnic and Demographic Changes in Hungary's (More Than) 1100 Years Long History
}

\section{Summary}

This paper will follow the ethnic and demographic changes of Hungary across the changing aspects of Hungarian history. It will discuss the issues of war, devastating sicknesses, migration and emigration.

Keywords: Holy Crown, assimilation, Habsburg Empire, sovereignty, integration

Thinking, attitudes to life, faith, way of life, family, social and other circumstances and the concepts describing and defining them are subject to constant change. Spoken and written words have changed and meant different things over time. Projecting back our current notions to the distant past can lead to misunderstandings and misinterpretation. Assuming this the author will try to be faithful to the period, to be clear, and to simplify complicated events, knowing for sure that this is not completely possible. Since the demographic and ethnic situation is determined most of all by history, wars, devastating diseases, migration and emigration, among the possible approaches these events form the basis of and framework for this study.

Hungary, or the Hungarian state, has existed for more than 1100 years. If we used the notion of the 'state' in the sense conceived by historians of law, historians, sociologists, social and cultural anthropologists, then Hungarian statehood was founded in the middle of the 9th century by King Stephen I's ancestor Álmos, when he was

Dr Miklós Kásler, PhD, DSc of the Hungarian Academy of Sciences, director, professor (m.kasler@oncol.hu). 
elected to be the reigning prince in Etelköz, the land where the Magyars (ancient Hungarians) stayed before their conquest of the Carpathian Basin. The state is an institutional supreme authority, independent from external powers, and enforced on the population of a specific geographic area. To the extent that the state functions in order to achieve the supreme common good as defined by Aristotle, it might be considered the political expression of the will of the community. Beside all this, it is also characterised by the acceptance of the governing power, integrity and a spiritual sense of interdependence.

The common will of the Magyars living in Etelköz was directed towards the conquest of the Carpathian Basin, which was successfully accomplished in the second half of the 9th century, and therefore the statehood of the Hungarians in Central Europe has more than 1100 years of history (Szabados, 2011). The adoption of Western European norms, of course, commenced with the re-establishment of the state on a Christian basis by Saint Stephen (King Stephen I), building on the foundations of Grand Prince Géza (Veszprémy, 2002). There are elements of these norms still operating today, such as codified legislation, literacy based on the Latin alphabet, public administration organised on a territorial basis, and the first Hungarian work on the theory of the state - the Admonitions (De institutione morum) written for Prince Emeric - by Stephen I. (Havas, 2005).

The other community organising principle was ethnicity. In the Hungarian language this is reflected in the meaning of the word 'nép' (people), which is not identical to population. While population is a neutral term for all inhabitants within a given geographic area, ethnic community, an ethnicity is a community of traditions and common origin where the people have their own name and system of symbols. It is a fact, however, that these concepts are barely present in such a clear form during the eventful centuries of the Migration Period in Central Europe.

Hungarians are the living example that, beyond these notions, real communities are continuously changing and stirring.

The Hungarians own myth of origin (the legend of the Miraculous Stag) and the associated ethnic names Hun, Turk, Onoğur, Avar, Bashkir etc. indicate that the Magyar conquerors were originally from a steppe culture (Anonymus-Kézai, 2004). However, the evolution of the Hungarians did not come to a standstill with the settlement of the Carpathian Basin. 'Hungarians' is the umbrella term for the communities that arrived in waves and settled down in the Carpathian Basin. They were ethnically Magyars, local Avars and Slavs, Pechenegs, Oghuz Turks, Cumans, Jász, Franks, Italians, and newcomer Slavic and German groups. They believed in the gods, or in Christ from a Byzantine, Roman or Reformed perspective, or practised the Muslim or Jewish religion. The adopted ethnic groups brought with them their languages, traditions, customs, warfare and culture. Although the relative proportions of these populations were different at specific points in time, they increasingly became homogenised and assimilated over the centuries, thus enriching the multi-rooted Hungarian nation. The people, stratified in different ways in social terms, were called the regnicola (inhabitants of the country). They formed society and the state (regnum, archiregnum), 
which provided a liveable framework for the inhabitants based on the force of law - despite the storms of history - until the peace agreement of the Treaty of Trianon. The organic development of Hungarian law was interrupted in the period of the 20th century dictatorships and took an entirely different course.

The reasons why the Carpathian Basin was conquered are not known for sure. The numerous theories centre around two marked but not proven opinions. According to one, seven 'Magyar' tribes of similar origin quit the Khazar alliance, and were joined by three related Kabar tribes. The wave of migrations that began in the surroundings of the Caspian Sea pushed the Oghuz Turks westward, who defeated the Pechenegs, and who in turn destroyed the Hungarian homeland. Thus fleeing Hungarians were forced to conquer the Carpathian Basin. The logical weakness of this theory is that it is based on an ancient Greek trope (Szabados, 2010). According to this, attacks from the east defeat and disperse towards the west to their neighbours who, in turn, albeit weakened, conquer their western neighbours at their strongest. At the end of the domino effect, in 895 the dispersed Hungarians conquer the vast expanses to the east and north of the Danube, and by 900 they occupy the entire Carpathian Basin. They abolish the supremacy of Arnulf, the King of East Francia and, moreover, in 899 they defeat the greatly superior army of Berengar, the King of Italy, near the river Brenta. On top of all that, the Hungarian empire was solidified by the Battle of Pressburg in 907, which ended with the humiliating and total defeat of the Frankish army marching to take back the former Frankish territories (Veszprémy, 2008).

The other opinion is the conviction of dynasty. Based on the surviving native and foreign chronicles, history books and folk traditions, it was unanimously accepted until the 1850s that the Magyars' sacred grand princes, the descendants of Attila (the Turul peoples) were empowered with a heavenly mission to invade the central Danube basin.

Even though the Attila tradition of the Árpáds can be accepted as an authentic belief (Dümmerth, 1996) it in itself does not answer the question of the conquest of the Carpathian basin. The cause was, on one hand, the establishment of the Magyar steppe state as a new power factor emerging in Etelköz under the leadership of Álmos and, on the other hand, the attractive natural geographic conditions and political division of the Carpathian Basin. In the light of more recent observations, the conquest itself could have been a long, deliberately planned process that started in the mid-9th century and lasted until around 895; it started with Grand Prince Álmos and was fully realised during the rule of his son, Árpád.

Since the decline of the Avar Khaganate in the early 800s did not result in genocide, the various ethnic groups - Avars (among them the Onogur proto-Hungarians and the Szeklers?) and Slavs - inhabited this area, accompanied by Frank and Bavarian settlers in Carolingian Pannonia. Álmos' and Árpád's people came to know these relationships and with this knowledge they successfully carried out the state-political integration of the Carpathian Basin under Magyar leadership. The process of the deliberate Magyar conquest did not result in any demographic shock for the Carpathian Basin. 
The number of the conquerors is estimated by the author at around 250-300,000. The size of the population in the Carpathian Basin in the decades before its conquest is estimated to be 300-400,000. Their composition and location are summarised in Table 1 based on historical and archaeological data. It should be emphasised, however, that this is to be regarded as only a historical reconstructive possibility.

Table 1: The population of the Carpathian Basin before its conquest (9-10th century)

\begin{tabular}{l|l}
\hline $\begin{array}{l}\text { Vassal nations of the Carolingian } \\
\text { boundary culture (from the Istrian } \\
\text { peninsula to the Czech Basin) }\end{array}$ & $\begin{array}{l}\text { Avars (40-45\%) } \\
\text { Franks (40-45\%) } \\
\text { Byzantine fragments (typical finds) } \\
\text { Slavic fragments (atypical finds) }\end{array}$ \\
\hline Transdanubia & $\begin{array}{l}\text { Avars } \\
\text { Franks }\end{array}$ \\
\hline Upper Hungary (Slovakia) & $\begin{array}{l}\text { Slavs (from Košice to the Plain of Szatmár and to the } \\
\text { Transcarpathian Oblast) } \\
\text { Finds of unidentified origin }\end{array}$ \\
\hline Transylvania & $\begin{array}{l}\text { Avars (south of the Arieș River, along the Mures } \\
\text { River and scattered) } \\
\text { Bulgarians (Lower Danube and scattered) } \\
\text { Slavs (Northern and Eastern Transylvania) } \\
\text { Szekler (Northern Transylvania, northern areas of } \\
\text { Bihor County and the Partium) }\end{array}$ \\
\hline Hungarian Great Plain & $\begin{array}{l}\text { Avars (across the Great Plain) } \\
\text { Bulgarians (scattered around the Tisza region) } \\
\text { Magyars (Transcarpathian Oblast, Upper Tisza } \\
\text { region, Bodrogköz) }\end{array}$ \\
\hline
\end{tabular}

Source: The author's compilation

During the 100-year reign of the grand princes, the Magyar medium-sized power was wedged between the Byzantine Empire, and the Eastern Frankish Holy Roman Empire. During this time, while always being part of an alliance, the Magyars prevented and delayed the strengthening of their two powerful neighbors with "plundering raids" and preventive campaigns to the west and to the south. Nothing could happen in Europe between 907 and 955 against the will of the grand princes. The army of a few thousand horsemen, however efficient, was not suitable for leading marauding campaigns - ships and chariots would have been needed for those - but during their expeditions, which were sometimes thousands of kilometers in length, they could plunder precious metals, prisoners and animals. The ethnic and religious situation was further complicated by voluntary migrants and those seeking asylum, in addition to the captives. The Battle of Lechfeld in 955 and the Battle of Arcadiopolis in 970 concluded the period of the preventive campaigns to the west and to Constantinople, respectively. Human losses in these wars were negligible, since they were fought by armies of only few thousands troops. Despite the defeats - in the absence of a dominant position - between the years 907 and 1030 (the imperial army of Conrad II, the Holy 
Roman Emperor) the country was not attacked from the outside. Byzantine and Roman missionaries could evangelise freely and build monasteries, the numbers of their followers grew and their servants were allowed to settle down, while trade was secured to all points of the compass. Three years into his reign, in 1000, Grand Prince Vajk (husband of Gisela of Bavaria, the sister of Holy Roman Emperor, Henry II) decided to officially convert to Christianity. Pope Sylvester II sent a crown, acknowledging the sovereignty of the Kingdom of Hungary (independent from the Empire) Hungarian Kingdom and the church organisation and proselytising of the king, who was canonised as Saint Stephen in 1083 ("I am Apostolic, while he is rightly the Apostle of Christ, if Christ converted so many people through him" - stated the Pope when sending the crown, according to the hagiography written by Bisop Hartvik). Gisela was accompanied by many German and Italian knights and their household servants. A considerable number of missionaries came from Rome, although Byzantine monasteries were still operating at the time of the Mongol invasion (1241-1242) - despite of the schism of 1054 .

Settlers and refugees (Pechenegs and Bulgarians) increased the population more than did the emerging trade connecting the four points of the compass, and the traders and craftsmen who were making Hungary their home. The Admonitions of Saint Stephen, written for the benefit of his son Emeric, determined for a period of a thousand years that refugees and settlers should be accommodated without discrimination: “...as the guests arrive from different parts and provinces of the world, they bring with them different languages and customs, and a variety of teachings and weapons. They do honor to every kingdom and make the court magnificent, deterring foreigners who act provocatively. The kingdom which is built on a single language and based upon only one custom is, therefore, weak and vulnerable." The quote, written in contemporary Latin, signifies the accommodation of those foreigners who are worthy, have value and are willing to take a stand against attacks from the outside. It is not about the wandering masses, but about the voluntarily naturalized people, who are of quality. Even though Stephen I established a Carolingian state, his kingdom was not a feudal state in the Western European sense, since lands were granted for individual merits, and possession of land did not entail enforced service. This circumstance made settlement of foreigners desirable, and greatly strengthened royal authority. Thus the Christian Hungarian state was not established as a faithful copy of the Western model, but the Latin and German, or 'Roman', innovations were combined with the steppe legacy in a synthesis. The Kingdom of Hungary exhibited a strong and centralized sovereign power, in which there was no place for feudal lords who devastated and sacked each other's lands and people (Györffy, 2000).

Stephen I won every one of his military campaigns. Neither the armed clashes (within the dynasty) that preceded and followed his ascension to the throne, nor the defeat of the Bulgarians in alliance with Byzantine Emperor Basil II, nor the destruction of the attacking imperial army of the Holy Roman Emperor Conrad II caused any significant casualties. The same applies to the 11 th century after 1038 , although uprisings and fights for the throne followed after Saint Stephen's death. The spontaneous 
fusion and proliferation of society was ongoing. Since both Saint Stephen and all of his offspring married the children of foreign dynasties (dynastic marriages with the two empires are particularly evident), the ethnic mix of the ruling class was influenced by the settlement of the royal entourages. The ruling class from the conquest merged with local leaders, the elites invited in by the Árpád dynasty from surrounding countries and empires, including Germans, Slavs, Franks, Spaniards, Italians, and, during the reign of Sigismund and the Habsburgs, mainly Germans and Czechs. A significant proportion of Hungarian aristocracy originated from the Croatian ethnic group at a continuously growing rate from the time of Ladislaus I onwards. In the 19th century a substantial number of families of Jewish origin entered the Hungarian nobility.

The favourable demographic tendencies of the 11th century were not influenced by its four civil wars (in which the Holy Roman Emperor had intervened), or the defeat of the following: the German Imperial army seven times, of the Oghuz Turks and Cumans three times, the Bulgarians twice and the Polish once. The greatest military leader of the epoch, the first knight-king, Saint Ladislaus (King Ladislaus I) was alone victorious in eleven wars. As his sister's husband, Zvonimir of Croatia, died without an heir, the majority of the Croatian and Slavonian leaders invited Ladislaus to the throne. In the years 1090 and 1091 he occupied Slavonia peacefully and invaded Croatia and Dalmatia at the expense of small military conflicts. First he made his younger nephew, Prince Álmos, the Croatian king (Table 2), but when his elder nephew, Coloman the Learned, who had been King of Hungary since 1095, had himself crowned King of Croatia in 1102, a personal union was created between Croatia and Hungary. The personal union lasted 800 years without an armed conflict and to the mutual benefit of both nations, until the Treaty of Trianon. A substantial part of the Croatian nobility intermarried with Hungarians and the mixed marriages mutually enriched both nations.

\section{Table 2: Population growth up to the death of Ladislaus I (11th century)}

\begin{tabular}{l|l}
\hline Growing population & $\begin{array}{l}\text { Natural } \\
\text { Queens' entourages (Russian, Polish, Norman, } \\
\text { German, Byzantine, Serbian) } \\
\text { Remnants of the defeated Black Cumans } \\
\text { (Oghuz Turks) (Eastern part of Transylvania) }\end{array}$ \\
\hline $\begin{array}{l}\text { Growth of territory and population } \\
\text { (personal-royal union) }\end{array}$ & $\begin{array}{l}\text { Slavonia (today Croatia today) } \\
\text { Croatia (today Dalmatia) } \\
\text { Dalmatia (Adriatic shore and islands) }\end{array}$ \\
\hline Defeats & $\begin{array}{l}\text { Seven German Imperial attacks (1030-1107) } \\
\text { Four civil wars in several stages } \\
\text { Three Cuman invasions }\end{array}$ \\
\hline
\end{tabular}

Source: The author's compilation

The first and the second half of the 12th century and the first half of the 13th century were characterised mainly by indecisive clashes with Byzantium and (up to the Mongol invasion) by the successful establishment of a series of vassal states around 
Hungary (Table 3). The losses arising from the short biennial military campaigns were not significant. Many crusades marched through the country and the fifth crusade was even led, in 1217, by Andrew II to the birthplace of his mother (Agnes of Antioch). It was of great significance that Andrew II granted the Teutonic Order settlement in southern Transylvania in order to evangelise and civilise the Pechenegs and Cumans, who had fled from the Mongols and settled down in Wallachia, and the Vlachs (Romanians) who were seeping into the Carpathian Mountains, and to protect the country. Moreover, he granted settlement to many Saxon hospites to serve the order of chivalry and to introduce various economic activities that were unknown in the country at the time. Yet Andrew II expelled the Order to Pomerania (Hóman-Szekfú, 1936) - because of its efforts to gain independence - while the hospites, who had multiplied to several hundred thousands, retained their privileges until 1848, having become one of the Transylvanian nations, the Universitas Saxonum. (Their cities and villages were transferred to Romania after the Treaty of Trianon, and were abandoned in the Ceaussescu period, when the 'Genius of the Carpathians' started to demolish Hungarian villages, while letting the Saxons go to Western Germany for a couple of thousand German Marks a person). Being a shepherd folk tending their herds in the Carpathians, the Vlachs barely suffered any losses for centuries, and increased their numbers rapidly. The nobles forced Andrew II to sign the Golden Bull in 1222 - the second in Europe, just a few years after the Magna Carta - which limited the previously very strong royal powers, although they were still strong afterwards, and included the right to armed resistance if the king were to violate the law. This is the legal foundation of later Hungarian wars of independence (Corpus Juris Hungarici).

Table 3: Trends in demography from Ladislaus I to Andrew II, 12th century and the first half of 13 th century

\begin{tabular}{l|l}
\hline Growing population & Natural \\
& Queens' entourages \\
& Settlement of the Teutonic Order and the Saxon \\
& hospites \\
& Admission of Jewish refugees \\
& Penetration of Vlachs (Romanians) \\
& Pecheneg refugees \\
\hline Losses & Byzantine wars \\
& Expansive wars (establishing vassal states in the \\
& South and east) \\
& Minor raids of passing crusades \\
& Expulsion of the Teutonic Order \\
\hline Growth of territories and population & Bosnia \\
& Northern Serbia \\
& Banate of Severin \\
& Ungaro-Valachia, then Wallachia and Moldova \\
& Galicia and Lodomeria \\
\hline
\end{tabular}

Source: The author's compilation 
The crown of Saint Stephen was becoming gradually more and more sacred and the concept - unique in Europe - that was being built around it at that time, the so called Doctrine of the Holy Crown, relates to what is mentioned above. According to the doctrine the Holy Crown took over the power of the "Holy Kings" and their role in forming and unifying the nation. The crown is holy, because it was delivered by the angels from Heaven, and the pope sent it to Saint Stephen who, before his death, offered Hungary to the Virgin Mary, and therefore the Holy Crown is the crown of the Queen of the World, who is the heavenly patroness of Hungary. It connects Hungary to God, the heavenly power to the earthly power. Consequently, the Holy Crown is not an object, but an idea, an independent personality, the depository of the sovereignty and integrity of the nation, the possessor of complete authority that cannot be possessed by any man or group of people. The Doctrine of the Holy Crown has changed through the age. It was understood as the King from the very beginning up to the early 13th century, however because Admonitions is in favour of the pious exercise of power and is strongly against oppression, therefore the Doctrine of the Holy Crown excludes any form of dictatorial or despotic methods of governance from the beginning. Even in this early, personal era the Crown symbolizes statehood. The regnum is the country and the object of governance. From the 13th century onwards, the concept of the crown also included the subjects, thus it was not the Holy Crown symbolising the state that changed, but the state that it symbolised. When Władysław III ascended the Hungarian throne in 1440, he had no dynastic ties to his predecessor, but became king exclusively through an election. This demonstrates the non-perishing progressive power of the Doctrine of the Holy Crown. At the same time, the principle of election dates back to the Blood Oath in Etelköz, before the time of the kingdom. Although this knowledge survived in a Gesta which portrays the election of Álmos as a monarch through the notions of knighthood, but the blood oath itself was an ancient steppe custom as Herodotus also recorded it from the time of the Scythians. Therefore, the principle of the limitation of powers dates back to the time before the Kingdom of Hungary, however discussing this poorly attested issue would exceed the framework of this present study. The pertinent point now is the separation of powers under the aegis of the Holy Crown, which meant that the king's power was shared with the people (the political nation) - uniquely in Europe - not with the king involving the people in power, but the people electing the reigning monarch. This can be traced back to the 13th century, but it probably dates back longer, as the coronation is performed with the Holy Crown by the Archbishop of Strigonium (Esztergom) at Alba Regia (Székesfehérvár). All of these three conditions have to be met for the coronation to be considered legitimate. The king also involves the entire (political) nation in power but - and this is also unique in Europe - people do not serve the king (and, through him, the Holy Crown) because of an oath of fealty in exchange for authority (feudal hierarchy), but because they have previously earned it. The Doctrine of the Holy Crown therefore achieved, on one hand, the maintenance of a strong and efficient central power since there was no vassalage and, on the other hand, that every person in the Hungarian world was restricted in their power. (Using our current set of 
concepts, the expression 'democratic feudalism' could jokingly be used for this situation.) The doctrine was not influenced by oligarchs or by the periodic weakening or strengthening of royal power.

The Holy Crown ensures an eternal divine set of values and eternal values (fundamental principles of natural law) which are not to be questioned but are to be followed (good and bad, truth and injustice etc.). In the course of the development of the Hungarian legal system, this does not relativize, even after the Renaissance.

At the time of Andrew II, the Holy Crown, as the supreme authority, is the sole proprietor of the country based on tradition as well as law, therefore its wealth, land, mines, goods and chattels could never be sold, bargained or pawned, since the king and the people who form the nation i.e. the nobility (the members of the Holy Crown) are merely leaseholders and managers of the inalienable assets of the supreme power until the family line ends (entailment, which is abolished only in 1848) or until they become unworthy of the land gifted to them.

Because supreme authority is divided, measures must be taken to ensure balance between the powers of the nation and of the king (e.g. free election of kings, the coronation oath, the right of armed resistance against the king, the county system with local and later representative governments established by Stephen I, without the consent of which the king could not enact or enforce laws). When the king, the nation or any external force violates such rights, they are bound - even at the expense of armed conflict - to restore them. Its rights, being of heavenly origin, never cease to exist, but may only be temporarily suspended (Tóth, 2007).

The Doctrine of the Holy Crown also carries an enormous spiritual depth, because Saint Stephen is not only apostolic, like the Pope, but is an apostle, equal to the other apostles, and an evangelist of nations, in other words he and his descendants have a universal mission. Additionally, the country is the kingdom of the Virgin Mary, and hence any Hungarian king after Andrew II is also a king of Jerusalem. In the 14th century, the Kingdom of Hungary is the sole 'archiregnum' (the first, holy, ancient power that is capable of making the world work) in Europe.

During the reigning of Béla III (1172-1196) and his sons, Hungary again became one of the major powers (in Europe). The revenue of the country equalled that of the French and English kings, and by 1241 the population - 90-95 per cent ethnically Hungarian - was close to two million (Table 3). It was in this situation that the Mongols invaded Hungary. The Mongols defeated the combined armies of the Kievan Rus, the Cumans and other associated, smaller nations near the Kalka River in 1223, and resolved to attack Western Europe; they invaded Kiev in 1240 and conquered the steppe. The fleeing Cumans asked for asylum. King Béla IV took measures to protect the country - the nobles, however, viewed the Cumans as the advance party of the Mongols and chased them out of the country. According to some sources Batu Khan made an offer to Béla IV to attack the Western empires together. Such a force could not have been resisted by anybody up to the Atlantic Ocean. The 'kindred of the holy kings' could not accept this offer but, as always throughout its history and even against overwhelming odds, defended Christian Hungary and Christian Europe, the 'Schengen borders' of 
the time. The Mongols invaded from three directions. In the north, they overran the minor Russian principalities, the Polish and Silesia. The southern army troops broke through Bulgaria and Wallachia while the main army swarmed into the country across the passes of the eastern Carpathians. The royal army was lured into a trap and ambushed at the Battle of Muhi in March 1241, the occupied territories were devastated, and the inhabitants massacred. Béla IV did not receive assistance from either the Pope or the Emperor (who were at war with one another) or from any other Western ruler. The available military forces could maintain the line of the Danube until the winter of 1241. After the river froze, the Mongols crossed it and tore along Transdanubia, Slavonia and Croatia as far as Dalmatian Trau (today Trogir), chasing the king, but - most probably due to the election of the Great Khan - they then left the country.

The Mongol invasion was the first demographic catastrophe in the Hungarian history. According to an estimate the kingdom lost 30-50 per cent of its inhabitants. Today we think this is an exaggeration (Kovacsics, 1997). The destruction wrought havoc mainly on the rich plains to the east and north of the Danube, although the marshland of the Great Hungarian Plain and the forests of Transylvania and the Upper Hungary (Slovakia) hid away many inhabitants. Fortunately, the winter was very harsh and thus - even through plague broke out - it resulted in a significantly smaller epidemic than in western Europe. By 1242, Béla IV had already driven out Frederick II, Duke of Austria, from the Western counties occupied by him during the Mongol invasion, and Austria was divided up between 1242 and 1246 together with Ottokar II of Bohemia. During the rest of the century there were offensive military operations, the most significant ones being the victory at the Battle on the Marchfield (1278) and the elimination of the second Mongol invasion (1285). In order to recover some of the losses, the king granted settlement to numerous hospites and the Knights Hospitaller, and provided them with significant privileges. The king also granted refuge - after they had embraced Christianity - to 40 thousand Cuman families and to others fleeing the Mongols (Bulgarians, Russians, Pechenegs, Polish etc.) as well as to Jews, who were persecuted and harassed in the West. Vlachs were also seeping into the country at a growing rate. Among the settlers, the assimilation of the nomadic Cumans was difficult, eventually leading to armed conflict. However, at the Battle on the Marchfeld - won by Rudolph I of Habsburg, in alliance with Ladislaus IV, against Ottokar II, who was part of the Árpád dynasty on the female line - the Cuman advance parties have fought with cries of "Jesus! Jesus!". The Kingdom of Hungary remained a major player in Central Europe after the Mongol invasion, but its position as a major power was, however, only reestablished by Charles Robert of Anjou (the grandson of Charles II the Lame of Anjou and Mary, the daughter of Stephen V) - who emerged victoriously from the dynasty struggles between the three dynasties on the female line of the House of Árpád [the Wittelsbach, the Přemyslid and the Anjou dynasties] after the "Kindred of the Holy Kings" ended on the male line - and his son, Louis I (Louis the Great). After dealing with the coastal situation (Adriatic Sea), Charles Robert strengthened the southern and eastern defensive lines of the country, the banates and vassal principalities. He also wanted to secure the country towards Bohemia and 
Poland in order to reclaim his rightful inheritance, the Kingdoms of Naples and Sicily. In 1335 he organised the famous Congress of Visegrád (from which the cooperation of the Visegrád Four arose upon the initiative of József Antall), attended by the Bavarian, Polish, Bohemian and Hungarian monarchs. The kings agreed on the spheres of interest and alliances in Central Europe. The key consequence of the meeting was that Habsburg endeavours were concluded in the region for two centuries, peaceful decades followed and after the death of Casimir III the Great, Louis inherited the Polish throne. His successor on the Polish throne was his younger daughter, Hedwig, who married the Grand Duke of Lithuania, Władysław II Jagiełło - who, in turn, converted to Christianity - therefore unifying the two empires (Dümmerth, 1982).

Figure 1: Demographic map of Hungary based on population density

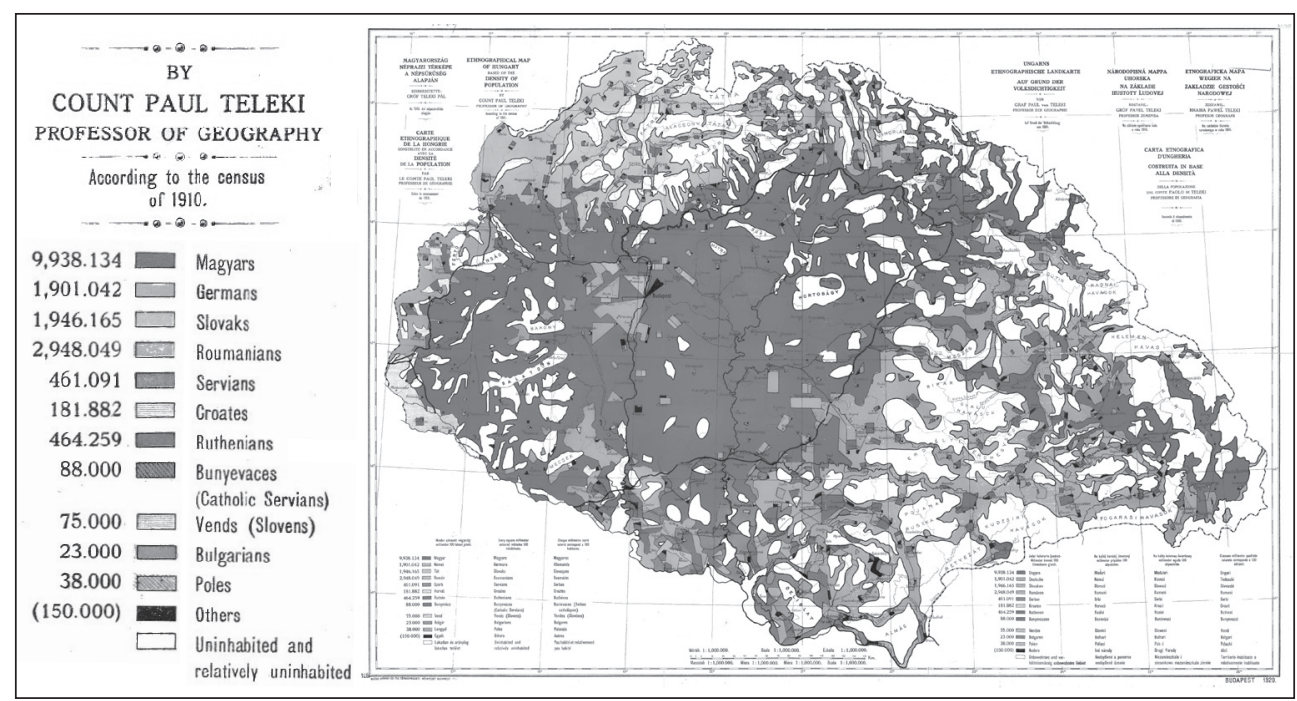

The Kingdom of Hungary reached the peak of its power in terms of political influence as well as militarily, geographically, and economically, during the reign of Louis I. During this time the population grew substantially, while no major ethnic changes occurred. No substantial casualties occurred in the struggles for the throne and in the various military campaigns, because a large number of foreign mercenaries fought in the major expeditions outside the boundaries of the kingdom. The Black Death, the plague epidemic that exterminated 30-50 per cent of the European population, was introduced by the soldiers who took part in the Neapolitan campaigns. Based on the public administration records and contemporary chronicles it is most probable that mortality did not approach the European rate in Hungary. Leprosy was also only encountered sporadically (Ember, 2007).

During the reign of Sigismund of Luxemburg, the successor through the Anjou line, and the following "mixed house kings" (of the Jagiellonian, Hunyadi and Habsburg dynasties), the Ottoman Turks gained a foothold in the Balkan and pushed 
northward. Throughout his long reign Sigismund, in the capacity of King of Hungary (1387-1437), King of Bohemia (1417) and Holy Roman Emperor (1433) changed the way and style of governance. He mainly pursued an imperialist policy; in the first period of his reign, he expanded to the west by relying on Hungarian resources, settled church matters at the Councils of Constance, Basel, Florence and others, deposed the antipopes, sentenced Jan Hus to be burned at the stake, and fought with his Hussite followers. He also interfered with the attempt to establish an independent French church. Sigismund was a European monarch of broad vision, who tried to establish an empire. Though his role model was Ladislaus I - Sigismund was buried next to him and his first wife, the daughter of Louis the Great - he planned to rule over his empire from Buda. His travels in Europe, diplomatic activities and the struggle for the thrones and those against the Hussites occupied all of his attention. Even through Louis the Great disbanded the Ottomans in the vassal states (the first line of defence), during the reign of Sigismund the Turks broke through it. They defeated the Serbian vassal state at the Battle of Kosovo (1389), and Sigismund lost a major battle in these territories (Nicopolis, 1396) with his international army due to the poor discipline of the French-Burgundian troops. He could not prevent the increasingly frequent Ottoman incursion and attacks on the border fortresses in the second line of defence, centred on Belgrade (C. Tóth, 2009). It can be assumed that Sigismund - like Matthias - wanted peace in the west so that he could turn the united Christian forces against the Ottomans. The Serbian despot, the Voivode of Wallachia and Moldova - depending on the balance of power - was, in turn, the vassal of the Hungarian king and the Ottoman Sultan. Minor military operations occurred every second year. Only the unrivalled military genius of John Hunyadi (c. 1407-1456) transferred the conflict to the Balkans again. While being constantly attacked, Hunyadi defeated the Ottomans in 14 military campaigns over a period of 17 years. He was victorious in six additional minor battles, and even his defeat at Battle of Varna (1444) set the Ottomans back to a great extent. After the sensational victory at Belgrade in 1456, the Sultan made only a few faint attempts against the Hungarian border until 1521 (however, he occupied several major islands in the Mediterranean and the northern states of Africa) (Pálosfalvi, 2005).

As the Ottomans attacked more and more frequently and with greater armies while the war with the Hussites was still ongoing - the Hungarian armies fighting were also becoming larger (during Hunyadi's 'Long Campaign' his army consisted of c. 30-35,000 men). Despite Polish assistance, the auxiliaries of the vassal states and the employment of mercenaries, the casualties were also growing. These losses however, were amply compensated by the Bosnians and the Serbians, who were streaming into the country in flight from the Ottomans, and the migration of the Romanians from Wallachia and Moldavia, who were fleeing from the cruelties of the Ottomans and their own Voivodes (the vendettas of the Dănești and the Drăculești families, the origin of the Dracula story). With the increasing number of the inhabitants the ethnic proportions changed, aided by the fact that refugees were allowed to retain their faiths. Immigration continued during the reign of his son, the excellent military lead- 
er, supreme diplomat and Renaissance ruler, Matthias Corvinus (1458-1490) - the strategist, diplomat and all-round Renaissance sovereign - who was able to maintain the sovereignty and integrity of the nation through his substantial and permanent armies, including a force of 6-8,000 mercenaries. The country could raise an army of some 160,000 strong, and its fleet consisted of 364 vessels (including 16 large galleons), equipped with the necessary manpower and weapons. He trained dozens of the finest vice-captains of Hungarian history. The number of war wagon carts was around 3,000. Only the emerging Ottoman Empire could raise an army that was comparable both in numbers and weaponry. Because of constant attacks from the west, Matthias decided to make peace in the west and in the north by the force of arms, so that he could rely on new resources to launch a later counterattack on the Ottomans. During the 32 years of his reign, he led 29 military campaigns. (In 1485, he became the second Hungarian king after Stephen I to conquer Vienna.)

Up to the death of Matthias, the sporadic outbreaks of plague - the result of the permanent state of war - and the cholera outbreak (1439) caused by contamination of drinking waters, in which King Albert and most of the army marching to release Smederevo died, had caused fewer casualties than wars and the captives taken by the Ottoman armies breaking into the country. For example one Ottoman army crossed the Danube into Transylvania in 1438 and destroyed Orăștie, Sighișoara, Mediaș and Braşov and then crossed the Carpathians with 70,000 captives. Massacres carried out by the akinjis and the vassals from the Balkans, who accompanied the main Ottoman army, were frequent and common.

In spite of all this, the population of Hungary kept on growing until the Battle of Mohács (1526), equalling the number of inhabitants of England, i.e. 4-4.5 million, 80-85 per cent of them ethnically Hungarian. The Romanians in Southern Transylvania, the Slavic fugitives from the Balkans in the Délvidék ("southern lands"), and the Czech Hussites remaining in Upper Hungary (Slovakia) changed the ethnic balance. The peasants' revolt led by György Dózsa in 1514 did not cause any demographically measurable damage either.

In 1520, the greatest emperor of the Ottoman history, Suleiman the Magnificent ascended the throne. He took Belgrade, Zemun, Šabac and other important southern castles in 1521 (thus causing the collapse of the secondary defensive line) and the remaining lesser fortresses of the southern defence system in 1526. Having conquered Northern Africa and Rhodes, the Ottomans launched an attack against Hungary in 1526.

Even though Louis II could only raise and send into battle half of the army, he undertook to engage the enemy at Mohács. After initial successes in the battle, he suffered a catastrophic defeat, losing 26,000 men against the greatly superior enemy. The King himself fell in the battle, so the troops that had been gathering at three different locations dispersed and a decisive battle could not be fought near Buda. The Ottoman army scorched both sides of the Danube (in the hills between Esztergom and Buda alone, more people were killed than in the Battle of Mohács), and left the country with an endless number of captivess. This was the end of the first half of the 300-years 
long Ottoman-Hungarian war, during which, between 1372 and 1526, Hungary was able to preserve with great effort its sovereignty and integrity, its religion, its status as a medium-sized power, and its ancient folk and European (Roman, Gothic and Renaissance) culture, while the population grew in numbers and wealth. This could be seen as a miracle, since by the beginning of the 1500 s the territory and population of the Ottoman Empire was five times and its revenues at least ten or fifteen times bigger than those of the Hungarian king. But then reality caught up when, step by step, the Ottomans captured Buda (1541) and one third of the country's territory to the west, east and south of it. That two kings were elected facilitated the conquest because the eastern provinces expected the most powerful baron of Transylvania, John Zápolya (with his wife was Isabella Jagiellon) to drive out the Ottomans, while in Western Transdanubia Ferdinand (the brother of Emperor and King of Spain, Charles V) was expected to accomplish the same. However, neither of the two parties was able to restore the rights of the Holy Crown. Zápolya tried to reach an agreement with the Ottomans, as did Ferdinand, while he waited in vain for assistance from the Empire, as Charles V was absorbed by the war against the French and the numerous problems in the huge empire, including the claims of the German Electors who had converted to the Protestant faith. The legal continuity of the Kingdom of Hungary (which had actually lost two thirds of its territory) was declared in the Treaty of Speyer (1570), and a relatively independent state, Principality of Transylvania, was established, representing the idea of the Holy Crown, and became the alternative to the unification of the nation, ensuring the development and culture of the three constituent nations, the Hungarians, the Szekler and the Saxon, and the other ethnic groups as well (R. Várkonyi, 1999). The leaders and soldiers of the 'Ottoman territory' in the middle were mainly southern Slavs, mostly Bosnians supplemented by Albanians. The Turkish ethnic groups marched across the country during the major campaigns, feeding the army by robbery, killing off the inhabitants and taking prisoners, although the Ottomans did not want to exterminate the population but impose taxes and plunder them. There were constant fights along the line of the border fortresses until the end of the Ottoman occupation, and smaller groups moving to and fro also fought each other. Owing to the conflict over the course of 150 years, south Slavic peoples became the dominant population in the southern territory (the area between the rivers Sava and Drava), while Zápolya granted the right to settle to Cserny Yovan ('the Black Tsar') in the Bačka and Temesköz (Banat plains) regions. Incoming Serbs killed off the great part of the remaining Hungarian inhabitants until Zápolya destroyed the marauders (1527). The indigenous Hungarian population of the Banat could never fully recover from this. The second demographic disaster was caused not by the above events but by the so-called Fifteen Years War (1593-1606), when substantial mercenary armies (20 to 40,000 in number) under Austrian command liberated some Ottoman castles in Trandanubia, devastated the area and crossed the Danube to march against the Sultan who was approaching the Great Plain with an army of 150,000 troops. Both armies caused extreme devastation during the military operations, exterminating a significant portion of the population. The fights also spread to the southern territo- 
ries and to Transylvania. The situation was consolidated by Bocskai, while Gábor Bethlen (1613-1629) fought against Ferdinand II, the Holy Roman Emperor in two wars (1619-1621, 1623-1626), while the economy, industry and culture of Transylvania prospered. The campaigns of the Habsburgs and the Ottomans and occasional attacks by Tartars reduced the number of Hungarians, mainly those living in the river valleys. The Tartar campaign after 1657 and the Ottoman campaign of 1660 were especially devastating. Romanians settled from the mountains to replace the exterminated inhabitants. During the rule of Gábor Bethlen, approximately 80 per cent of the one million inhabitants of Transylvania were still either Hungarian or Szekler (Székely), the rest being Romanians and Saxons. By the time the Ottoman were expelled, only half of the inhabitants in south and central Transylvania were ethnic Hungarians. In the 1600s, for example, in 46 of the 106 villages in Szilágy (Sălaj) County, the Romanians became a majority, while ethnic Hungarians were displaced in 55 communities of 112 in Kolozs (Cluj) County.

The expulsion of the Ottomans began with the siege of Vienna in 1683. After winning the Battle of Kahlenberg (for which Sobieski, King of Poland, deserves credit) the allied troops of the Holy League, led by an Imperial Commander and enjoying substantial Hungarian participation, had liberated the entire territory of Hungary from the Ottoman rule by 1689 , and then made deep inroads into the Balkans. At that point Louis XIV of France, in order to relieve the Ottoman Empire which was regarded as a 'friend', terminated the armistice that had been concluded for a period of 20 years and, therefore, substantial military forces and excellent military leaders had to be reassigned to the French border. The resulting Ottoman counter attack reconquered the Balkans but the last large assault by the Sultan after a few years of static war was smashed by Prince Savoy in 1697 at Zenta. Only the Banat plains were left in Ottoman hands up to 1716-1718. The last 15 years of the 300 year long war restored the integrity of Hungary, but at the cost of yet another demographic disaster.

Between 1526 and 1697 the population of the country was reduced from 4.5 million to 3.5-4 million. The losses were increased by periodic outbreaks of plague and typhus (described by Cardano as morbus hungaricus), introduced by the Ottoman army in 1542 when it marched from the Balkans to Buda. The number of Hungarian fatalities was up to 30,000. In 1544, the Christian army that set off to recapture Buda also lost 30,000 thousand people without having fired a single shot (Szakály, 1986). Therefore it was in this period - in the two Fifteen Years' Wars (1591-1606, 16831699) - that the ethnic composition of Hungary changed substantially. Significant loss of lives was caused by the fights and campaigns in the Ottoman-occupied Great Plain and its border areas, by the Habsburg campaigns in Northeast Hungary, and by the incursions of the Tartars and Turks in Transylvania.

The expulsion of the Ottomans was not accompanied by enthusiasm and was not preserved in the memory as would be justified by its significance. The war that dragged on for 15 years, then the movements of the Imperial army of some 50-60,000 thousand people wintering in and fed by the country, was accompanied by extreme deprivation. Special taxes were levied, the Neoacquistica Commissio demanded presentation 
of the original title deeds - after 150 years of plundering, arson and flight - and if the estate was restored successfully then 10 per cent was confiscated as war contribution. The looting of the country was accompanied by the deprivation of rights. The Diet waived its right of free election of the King (1687), Transylvania was subject to separate governance by the Hungarian king (and Holy Roman Emperor), although it remained part of Holy Crown (Diploma Leopoldinum), the rights of the estates were impaired as well the freedom of religion guaranteed by the Diet of Torda (1568). The expulsion of the Ottomans was accompanied by deep despair in all layers of society. The above reasons triggered the Kuruc movement, which gave rise to Rákóczi's War of Independence (1703-1711) ("cum Deo pro patria et libertate").

The 18th century was determined by three peace treaties. The Treaty of Karlowitz (1699) restored the integrity of the country, while impairing sovereignty and ancestral rights, the Treaty of Szatmár (1711) settled the constitutional and other relations of Hungary, while the Treaty of Utrecht (1713) defined the place of the Habsburg Empire in Europe (the Empire was pushed back to the areas along the Danube, and so the value of Hungary within the Empire was raised).

Rákóczi's War of Independence resulted in a military situation that varied for years, the fight affected all parts of the country several times and the military campaigns consumed whatever was left after the expulsion of the Ottomans (Tamás, 2003). Hungarians also fought in the Imperial Army, and so the conflict also had the characteristics of a civil war and, in addition, the large number of Serbs living in the southern territories also rebelled in an effort to support the Emperor and decimated the natives communities, Hungarian and Croatian alike. This was the second episode of genocide in the southern territories. The Kuruc uprisings against the Austrians (1687-1699 and 1701) and the War of Independence caused around 30,000 fatalities. The eruption of plague took the lives of ten times as many people (approximately 300,000). These events caused another demographic disaster. The total population dropped to approximately 3.5 million with the ratio of ethnic Hungarians falling to around 35 per cent. The Treaty of Szatmár that ended the war was reasonable and as a result, a cultural consolidation could begin in accordance with the constitutional, political and social character of the country. The reformation movement significant in the previous century, was followed by a peaceful counter-reformation. While armed wars of religion and retribution have taken place in almost all Western countries, this has never happened in the 1100 year history of Hungary. Destroyed populations were spontaneously replaced in the middle of the country, in the plains and in river valleys by settlers coming from the peripheries, the Carpathians, and beyond. This is how Slovaks settled in the south of the Great Plain, and the Romanians of Moldova and Transylvania in the east and north of the Great Plain, and in the Transylvanian basin, with the exception of the Szeklerland. The Croatians moved towards the north on the western border, as did the Serbs on both sides of the Danube. The remaining Ottoman soldiers, mainly south Slavs and Albanians, integrated quickly and unnoticed, and the 200,000 Serbian refugees did so partially. Ethnic diversity was further enhanced by the fugitive Armenians and Roma. A great number of foreigners were 
settled by the ruling houses and a few major barons, mainly Catholic groups of German origin, granted them substantial privileges in the southern territory, in Upper Hungary (Slovakia), Southern Transdanubia, and in the areas where Transylvania and the Great Plain meet. Spontaneous and organized migration consisted of populations that were ethnically different, but culturally similar, practicing one of the rituals of Christianity, who accepted the supreme power and the laws, and who mostly adapted to the habits of the tolerant host country.

After the Treaty of Utrecht the Danube Monarchy was outlined, the provinces of which were governed by the ruler as the Holy Emperor while the Kingdom of Hungary and its provinces were governed by him as the King of Hungary. It remained a characteristic feature throughout this century that the Emperor or Empress acted as a paternal (Charles III and Maria Theresa) and then as an absolute (Joseph II, 17801790) but enlightened despot, promoting the interests of the Empire by trying to reduce the rights of the Hungarian estates, while the estates successfully resisted these efforts by referring to the ancestral Constitution (the Doctrine of the Holy Crown) and to the oath of the king. Both the king and the estates tried to expand their powers. They could do so because the Empire would not have won its wars without the Hungarian military forces, raw materials and agriculture, and neither could it have maintained its rule, which extended to the female line after 1740 (Habsburg-Lothringen dynasty), and its status as a great power ("Vitam et sanguinem") (Marczali, 1997).

Industry developed mainly in the Austrian, Bohemian and Moravian provinces, while agriculture dominated the territory of the Kingdom of Hungary and in Transylvania, and was also promoted by the disputed 'dual customs system'. As a result of spontaneous migration and the arranged settlements that occurred under Charles III and, especially, under Maria Theresa, the population of the country grew fast, especially the Romanians, who were driven across the Carpathians by the miserable situation in the principalities of Moldavia and Wallachia. The numbers of several hundred thousand Serbian refugees, who arrived in Hungary during the Ottoman wars and even after 1690, grew similarly. Romanian and Serbian peasants and shepherds settled down in blocks, while the German (Swabian, Walloon, Saxon etc.) settlers were scattered around, mainly in major towns (most of them were artisans and traders). By 1785 - according to census figures - about 38 per cent of the approximately 8 million inhabitants were Hungarians. This is the first time that the ratio of the Romanians exceeded 50 per cent in Transylvania. The growth of the population was hardly affected during the century by the three wars against the Turks (during the reigns of Charles III and Joseph II) and the two Western wars (under Maria Theresa). However, it was affected by the peasant revolt led by Horea-Cloşca-Crişan (the 'Vlach Emperor'), which resulted in the deaths of 60,000 ethnic Hungarians, mainly in and around the Metaliferi Mountains of Transylvania.

In the last half of the 18th century and the first half of the 19th century decadeslong disputes began in the circles of the Hungarian nobility on the necessity, contents and method of the bourgeois transformation, which would take place constitutionally and peacefully within the Habsburg Empire, based on the sovereignty and integrity 
of the country. This process involved the alignment of the ideas of the Age of Reason with the ancestral constitution. The brutality of the French revolution and the terror of the Napoleonic wars went against the Hungarian traditions and mind set, so radical solutions were disregarded. However, national feelings were strengthened, in the sense of patriotism as opposed to nationalism. The latter was characteristic not so much of the Croatians, but rather of the Romanians, the Serbs and later the Slovak elite, with a few decades of delay and relying on historical precedents that did not exist.

While in the 18th century the royal and imperial family made efforts - giving priority to the interests of the Empire - to extend the rights of the lower social classes and to promote wealth accumulation by them, in the first half of the 19th century the Hungarian nobility initiated bourgeois transformation with increasing determination. Count István Széchenyi ("the greatest Hungarian”) mainly promoted economic reforms, while Kossuth focused on social reforms Hermann-Závodszky, 1999).

The wave of revolutions in March 1848 (Paris, Italy, Vienna etc.) accelerated the events. The Lower and Upper Houses of the Diet of the Estates voted elaborate and well prepared bills into law on 13 March, and after a lengthy dispute, the king (Ferdinand V) signed them on 11 April. These laws provided the fullest guarantees for the civic and social transformation, and the nobility surrendered their privileges voluntarily and peacefully, which was unique. The dynasty deposed Emperor Ferdinand $\mathrm{V}$ (Hungarian law does not recognise the abdication of the king), and Franz Joseph I was appointed to be emperor. However, he could not become Hungarian king because the previous king was still living, he did not take the oath on the ancestral Hungarian Constitution and several conditions necessary for the inauguration of the Hungarian king were not met. He cancelled and rejected the 1848 laws in his capacity as Emperor of Austria (which he was not entitled to do), incited rebellion among the Serbs and part of the Romanians and the Saxons of Transylvania and mobilised his armies. Despite the lack of international assistance, the first Hungarian Prime Minister, Count Lajos Batthyány organised the state administration and war industry, issued new money, organised an army which defeated the Imperial Army led by Jelačić at Pákozd at the end of September and pushed it back to the Austrian border. Initially, the imperial counter attack during the winter was successful, but in the 'spring campaign' the Hungarian troops - featuring excellent commanders and superior fighting morale - routed the demoralised remains of the Imperial Army in a series of victorious battles, pushing them back to Vienna, while General Bem achieved substantial successes in Transylvania. Emperor Franz Joseph appeared before the Russian Czar in Warsaw and kissed his hand, resorting to entreaties for his intervention. In accordance with the Holy Alliance, the Czar ordered Prince Pashkievich to attack Hungary with an army 200,000 strong. The Hungarian troops, attacked from three different directions, were concentrated around Oradea and Timișoara, but Arthur Görgey (one of the most ingenious military commanders of the century) realised that the still intact Hungarian army of 30-35,000 troops could not possibly defeat two armies of 100,000 men each and surrendered to the Russians in the middle of August 1849 
(Hermann, 2001). The surrender was followed by brutal retribution and disenfranchisement which was illegitimate under Hungarian law and can only be compared to that made by Kádár after 1956. (Lord Palmerston wrote to the English Ambassador in Vienna, "The Austrians are the biggest brutes among those who ever usurped the name of civilised people, their cruelty $[. .$.$] in Hungary and Transylvania can only be$ compared to the acts of negroes in Africa and Haiti.") The Emperor ruled the country administratively by decrees, to which the nation responded with passive resistance. Franz Joseph participated in the anti-Russian coalition of the Crimean war (he bit the hand that he had kissed in 1849), tried to prevent with force of arms the creation of two large nation states, Italy and Germany, but was defeated in every war (the loss of Lombardy and Venice, the little Germany solution under Prussian leadership). After defeat at the Battle of Königgrätz, the dynasty realised that they needed to compromise with Hungary. A large number of ideas were discussed during negotiations that lasted several years. Ferenc Deák ("the Wise Man of the Nation") found the solution which complied with the ancestral Hungarian legal system derived from the Doctrine of the Holy Crown, the agreement between the dynasty and the estates (Pragmatica Sanctio), the laws of 1848, the interests of the contracting parties and the need to settle the common affairs (military, financial and foreign). After the Compromise ('settlement') Emperor Franz Joseph took the ancestral royal oath, and was crowned with the Holy Crown by the Prince Primate (the Archbishop of Esztergom) as King of Hungary, Croatia, Dalmatia, Rama, Halitch, Lodomeria, Jerusalem, etc. This was followed by the Hungarian-Croatian compromise of 1868. The elected parliament guaranteed personal freedom rights, civil rights and cultural autonomy for its citizens, and one of the first laws allowed unlimited and unconditional immigration into the country (Gergely, 2005).

The country experienced breath-taking development in the fields of economy, culture, health care and education. The GDP grew fifteen-fold and the railway and road network tenfold. Growth in other areas of the economy was similar to that. Hungary produced one of the highest rates of development in Europe. One issue, however, could not be solved: the matter of the nationalities. A part of the religious and political leaders of the various ethnic groups recognised their ethnic identity in the 19th century. Their Hungarian identity was gradually supplemented with or partly replaced by an affinity with the neighbouring populations of the same origin that still partly lived under Ottoman rule. A number of myths were created and elevated to become 'scientific facts': the Slovaks referred to Greater Moravia, the Romanians to the Daco-Roman theory, the southern and northern Slavs to the ideal of Pan-Slavism, and the Czechs to their state within the Holy Roman Empire before 1620. Several proposals were put forward, some of them extreme, both by the Dualist state and the nationalities. They were either unfeasible or contradictory (e.g, the Slavic capital should be Prague, Zagreb or Belgrade in the case of a trialist state) (Zeidler, 2008).

Significant changes took place in Europe over the centuries. New political and economic powers emerged while others weakened. Emerging interests, occasional alliances and the wars that followed created two major systems of alliances in Europe: 
the Central Powers and the Entente cordiale. The population of the Kingdom of Hungary was about 10 million by 1848, with a 40 per cent ratio of ethnic Hungarians. In 1869 the native population was 13.6 million, 6.2 million of them ethnic Hungarian. According to the last authentic census made in 1910, 54 per cent of the 18 million citizens (9.9 million) were ethnic Hungarians (Figure 2). The population was reduced by the wars in the 19th century, permanent emigration to America totalling up to one and a half million by the time of World War I, and by epidemics. French prisoners of war captured in the Battle of Raab (Gyôr) during the Napoleonic Wars caused a typhus epidemic in Pécs. In 1831 a cholera epidemic swept across the country, taking victims mainly in Upper Hungary (Slovakia). Half a million people fell ill in the epidemic, and the loss in population was approximately 200,000. In the spring of 1848 cholera once again flared up in Croatia, then it spread to Transdanubia. This caused difficulties in recruiting soldiers for the Hungarian army, but it also prevented the Imperial Army of Jelačić from enlisting more men. The disease was brought in from Poland by the 200,000-strong Russian army led by Pashkievich, with approximately 80,000 soldiers falling ill and 10,000 dying. The most deadly epidemic was the diphtheria outbreak that started at the end of the 19th century, beginning around 1870 in France, killing 30,000 children each year. Plague disappeared at the end of the 17th century, smallpox was eliminated in the 19th century (thanks to vaccination), and epidemic typhus at the end of that century. On the other hand, tuberculosis (morbus hungaricus) appeared in the country, killing masses of people up until the 1930s, and could only be eliminated entirely by the 1940s and 1950s.

The ratio of natural growth within the Hungarian population increased constantly through the spontaneous assimilation of the nationalities and the significant integration and assimilation of Jews fleeing from prosecution in the Czar's Empire. Jews were allowed to flee to Hungary without restriction, since the Hungarian Parliament - the first in Europe - granted free immigration and full emancipation by law. The ratio of ethnic Hungarians despite the fact that in 1848-1849 Serbian insurgents organized themselves into marauding gangs and massacred masses of Hungarians, killing tens of thousands of people, and so did the Romanians in Transylvania, even though the laws of 1848 granted full rights to each inhabitant of the country, without exception. (The entire Hungarian population was killed in the small Transylvanian town of Nagyenyed/Auid and a pyramid consisting of several thousand skulls was erected in front of the Roman Catholic church. The same happened at Fehértemplom/Bela Crkva in the southern territory.) Major areas, towns and villages became depopulated. Horea's peasant uprising and the carnage of the southern Slavs fleeing the Ottomans in 1526 and after 1690 also had some ethnic characteristics, but at that time the aim was to acquire the land and wealth of the richer and more civilised natives. On the other hand, the mass murders of 1848-1849 were primarily ethnically motivated. However, a significant portion of the nationalities and numerous foreigners supported the war of independence, even in 1849, when the revolutions had been suppressed all over Europe.

In the Congress of Berlin of 1878, Bismarck and Count Gyula Andrássy (the common minister of foreign affairs) enabled independence for the Romanian principali- 
ties, then the Monarchy annexed Bosnia and Herzegovina, referring to the imperial of the kings of the House of Árpád - just as they did in the partition of Poland - but the Hungarian leading elite prevented annexation into the Kingdom of Hungary, owing to the deterioration of ethnic proportions.

The Ottoman Empire continued to lose its power in the two Balkan Wars, then after a temporary strengthening of Bulgaria, the always Russophile Serbia became more valuable. The outbreak of the Great War was not unavoidable after the assassination of Franz Ferdinand, heir presumptive to the throne, and the ultimatum of the Monarchy addressed to Serbia was at first accepted, with the exception, among others, that the police force of the Monarchy should be involved in the investigation. (Now, in an era of Interpol and cooperation between the various intelligence services, this rejection is not understandable, as it was not understood at the time, either). The causes of the World War I, the driving force behind the failure of several attempts to make peace, the development of the conditions of peace, and then the historical events that have lasted up until our time are not known even today, or they are misinterpreted, distorted or, as the interests of the great powers were kept secret, these issues are subject to constant discussion. It was a fact, however, that the Hungarian Prime Minister Count István Tisza opposed the war, taking a stance against the German and Austrian commanders-in-chief, the political elite and the two Emperors. When he could no longer maintain his position, he demanded that the Monarchy declared that it had no aim of territorial expansion. The war broke out seemingly for prestige, degenerated finally into an ideological kind of war, and then peace was made based on the interests of the great powers. Two members of the Central Powers announced their neutrality, which was breached by Italy once (when she entered the war against her former allies), while Romania attacked the Monarchy in 1916 without a declaration of war, but the Central Powers destroyed the Romanian army with a small military force and marched into Bucharest. At the beginning of 1918 Romania signed a separate peace treaty, but before the peace negotiations it was again an ally of the Entente. Until 1916 it had been mostly the Central Powers that had won victories, but the entry of the USA into the war in 1917 resulted in a decisive material superiority for the Entente. The 14 points of U.S. President Wilson promised the opportunity of creating a fair agreement of equal parties, including the right of the nations for self-determination. But in reality, secret pacts were concluded. These secret pacts were enforced when the peace treaties were signed. After the halt of the German offensive of 1918 in the West and the breakthrough by the Monarchy at the river Piave, the Central Powers did not surrender but concluded an armistice, relying on the 14 points of Wilson. At the very beginning of October, Poland was reborn, joined by Galicia in the beginning of November, the Czechs became independent once more, the South Slavs were planning to set up their own state and the Romanians declared their secession. On 31 October Count Károlyi became the Prime Minister and the Republic was proclaimed. According to the cease-fire signed on 3 November 1918, until the peace talks each belligerent party would remain in its currently held positions. The Hungarian armies were stationed beyond the 1000-year-old border in every direction. The soldiers start- 
ed going home en masse, 40 per cent of the army in perfect order and with their weapons. At that point Minister of War Linder stated that he "did not want to see any more soldiers." Parallel with the demobilization of the armies, and mainly with the assistance of the French, the Romanian army, which had formerly been disbanded, and Czech and Serbian forces marched into Hungary, modifying the armistice line arbitrarily. After the terms of the Vix Note of March 1919 became known, the radical left made pro-Entente Károlyi resign. For a period of 133 days power was captured by the communists, the social democrats allied with them and the radical liberals, turning internal relations deadly and the maintenance of foreign relations impossible. The soldiers of the Red Army defended their country and defeated and drove back the Czechs who marched into Slovakia. The Szekler Division, a military unit of a few thousand people, that was set up despite the prohibition, slowed down the Romanian army for several months. At the request of the Entente Powers the Bolshevik regime withdrew the troops from Slovakia, while the Szekler Division fell apart after heroic battles. Most of the territory of the country was under occupation. A national army was set up in the city of Szeged and marched into Budapest. The temporary and then the elected Parliament inherited a hopeless situation.

At the same time, peace talks were in progress around Versailles. In the case of Hungary even the Americans gave up the 14 points of Wilson and enforced secret pacts made with leaders of the nationalities. The Hungarian delegation was not invited to the talks and so the accused party was not allowed to participate in the retribution trial and could not tell its arguments or defend itself. After the conclusion they were of the trial allowed to make a final statement before the "execution" (signing). At the same time, each of the demands of the neighbouring states on the Kingdom of Hungary was accepted, sometimes involving brazen lies (e.g. the claim that the river Ipoly, only a few meters wide, is a navigable waterway etc.). It is symptomatic that there were no references to the right of self-determination of nations or ethnic principles, but rather to falsified historical and economic interests. Considered a model liberal state until the Franco-Russian treaty of 1907, Hungary was portrayed by the successor states as the home of feudalism and suppression, a prison of nations. As Francesco Nitti, the Italian foreign affairs minister at the time stated, they wanted to execute Hungary and to bring it into an unmanageable situation. They almost succeeded (M. Kiss-Raffay-Salamon, 2011). Exactly two-thirds of the area of the country was torn away by a dictated peace, including 70-80 per cent of its industry, most of its railways and public road network, natural resources and best lands, and 95 per cent of its forests. Of the estimated 18.3 million inhabitants, including Croatia, 7.6 million remained. 10.6 million people were reassigned to the new countries, including 3 million ethnic Hungarians, 30.2 per cent of the detached population, who lived in blocks on the far side of the newly enforced borders (Table 4). It was at that time that the phrase "Hungary borders on Hungary" was created. A multiethnic, thousand-year-old constitutional state was terminated, carved up into seven parts, and such states were created in which the ratio of nationalities was higher than in the thousand-year-old Kingdom of Hungary (Figure 2). Each of the successor states has disintegrated, the first between 
1940 and 1945. One nation state has remained intact in the region: Hungary. One thousand years of history, the principles of geo-economics (the Carpathian basin is a perfect geographic and economic unit), the ethnic principle and the rights of nations to self-determination were all ignored. The population of the detached areas were not even allowed to decide their fate by referendum. In the town of Sopron the volunteers of the 'ragged guards' drove away the Austrian gendarmerie, then the citizens of this small town, most of them German-speaking people, decided to remain part of Hungary by a referendum won by a two-thirds majority. Similar results could have been expected elsewhere as well, since the intentions of the leaders of the nationalities and the opinion of the people often differed (the legal, economic and cultural situation of nationalities was much more favourable in Hungary than the situation of their fellow nationals outside the country).

Table 4: Share of the successor states of the Austrian Hungarian Monarchy of the territory and population of historical Hungary *

\begin{tabular}{l|l|l|l}
\hline Country & $\begin{array}{l}\text { Area } \\
\left.\mathbf{( k m}^{2}\right)\end{array}$ & $\begin{array}{l}\text { Population } \\
(\text { persons })\end{array}$ & $\begin{array}{l}\text { Of which ethnic } \\
\text { Hungarian } \mathbf{( \% )}\end{array}$ \\
\hline Czechoslovakia & 61,633 & $3,517,568$ & 30.3 \\
\hline Romania & 103,093 & $5,257,467$ & 31.6 \\
\hline Kingdom of Serbs, Croats and Slovenes & 20,551 & $1,509,295$ & 30.3 \\
\hline Austria & 4,020 & 291,618 & 8.9 \\
\hline Italy & 21 & 49,806 & 13.0 \\
\hline Poland & 589 & 23,662 & 1.0 \\
\hline Total loss & 189,907 & $10,649,416$ & 30.2 \\
\hline Hungary after Trianon & 92,963 & $7,615,117$ & 88.3 \\
\hline Historical Hungary & 282,870 & $18,264,533$ & 54.4 \\
\hline
\end{tabular}

* Figures excluding Croatia-Slavonia; based on the figures of the 1910 census on mother tongue Source: Ember, 2007

The occupying armies plundered the country (the Romanian army alone, which also occupied Budapest, robbed some 20-30,000 railway wagon's worth of goods, ranging from typewriters and furniture all the way to the entire machine stock of factories, and herds of horses and cattle); the armies took everything they could lay their hands on (Bandholtz, 1993).

In the restored Kingdom of Hungary the Habsburg dynasty was dethroned and, after Hunyadi and Kossuth, Horthy was elected to be the third governor of Hungary. He developed an autocratic political system that showed signs of both democracy and dictatorship, mainly under the leadership of Transylvanian aristocracy. Although recovery seemed impossible, state administration was organized, finances were consolidated, the economy was developed, the system of education was developed from primary schools all the way to universities, the complete political and economic blockade of the Little Entente was broken up, and the ethnic Hungarian communities in the 
'successor states' received support. The country operated one of the best healthcare systems in Europe, primarily on the basis of solidarity. Every branch of Hungarian culture flourished (e.g. music: Bartók, Kodály and Dohnányi), almost all of Hungary's 15 Nobel Prize winners completed their school education between the two world wars, Hungary was one of the first countries to develop cinematic art (some of the Hungarians involved in filming, e.g. George Czukor, created Hollywood), and the sportsmen who won two silver medals in the Hungarian national football team $(1938,1954)$ and those who came third in the Olympics of Berlin (1936) and Helsinki (1952) grew up at that time. The ethnic Hungarians of the successor states suffered from several kinds of discrimination, with the victors violating the Treaty of Trianon in several ways. However, the national unity of Hungary was strengthened substantially. Every Hungarian party and organisation in the home country and in the successor states concurred that Trianon was unjust and could not be justified by any means, and that the thousandyear-old integrity of the country must be restored, either with ethnic boundaries or wholly. Trianon allowed for peaceful revision, though no active support could be expected from England and France (they declared themselves uninterested in the first and second Vienna Awards, but were not opposed to them, leaving the decisions to the Germans and Italians). The events of the World War II are well known, of these I would like to highlight that Austria was united with Germany with extreme enthusiasm, approving the unification in referendum with a majority of 97 per cent. All the rest of the successor states disintegrated, and in Munich the four great European powers accepted the partitioning of Czechoslovakia. Czech manufacturing industry supported the Wehrmacht at full capacity, and the Slovak leader Tiso immediately formed a close alliance with Hitler.

Romania was partially dissolved and the Kingdom of Yugoslavia disintegrated to its constituent part in the course of a brutal civil war. Between 1938 and 1940 Hungary peacefully regained part of Slovakia, Subcarpathia and northern Transylvania.

In 1941 Hungarian troops marched into the other territory 12 days after the Kingdom of Yugoslavia was terminated by the secession of Croatia; Serbia, the only country in the region that defied the Nazis, was defeated by the Germans. The population welcomed the revision without almost any resistance, with great enthusiasm in every detached area. Hungary did not want to participate in the war, but did so after the Romanians, Slovaks and Croatians and, furthermore, because the geopolitical location of the country made neutrality impossible; after an act of provocation it entered the war, which it tried to leave after 1943, but without success (Püski, 2010).

The country was occupied by the Germans on 19th March 1944, and lost its independence, which was only restored in 1990. Prosecution of persons with patriotic rightist and leftist views began, several hundred thousand Jews were deported to Germany until the middle of the summer of 1944, then after the coup d'état of the Arrow Cross party (15 October 1944), this was increased further. The country became a battleground, it was devastated and plundered by the Germans, then by the Soviets. The communist regime was forcibly introduced by arms, terror, propaganda and the application of other Bolshevik means, overcoming significant resistance. Apart from 
some groups of the narrow elite echelons of the Bolshevik party, every group in society was injured legally, socially and economically. This became the cause of the revolution and fight for independence of 1956, in which a country of ten million took up arms to fight for freedom against a superpower. As in most cases during its history, Hungary did not receive assistance from any party, including the UN; no armed assistance came despite some uncertain promises, and so the Soviet Union successfully suppressed the fight for freedom.

After the retribution, in the Kádár era the communist system did not essentially change, but fearing a repeat of the revolution the leadership tried to establish more beneficial social conditions ("Goulash Communism"). While the great powers followed the apparently coordinated strategy of non-intervention, Hungary let the East German refugees across the border and into Austria in 1989. This tipped the first domino of the socialist countries, which in turn tipped all the others within a few months. The Treaty of Trianon once again proved unviable. The Soviet Union was terminated, and independent states with large Russian minorities declared their secession from it. Czechoslovakia split in two, and Yugoslavia fell apart in an extremely brutal war, with its nationalities acquiring independence. Hungarian minorities continued living in Slovakia, Ukraine, Slovenia, Serbia and Croatia, countries that previously did not exist before, and in Romania. The states of the region joined NATO and became or will become members of the EU.

From the outbreak of the World War I to this day, Hungary has lived through at least nine different and contradictory political and ideological regimes. After the kingdom, the Republic was established on 31 October 1918, followed by the Hungarian Soviet Republic. After its downfall the new regime that lasted until 19 March 1944 was a national - conservative - Christian state hallmarked with the name of Horthy, which was terminated by the German occupation and the Arrow Cross coup d'état after 15 October 1944. This was followed by the Soviet occupation after 4 April 1945, the regime of coalition governments under illegally expanding Bolshevik supervision until 1947, then came the Stalinist Rákosi dictatorship until 1956, the revolution and freedom fight between 23 October and 4 November 1956, followed by the Kádár regime, and from 1990 the parliamentary democracy established by parties that won free elections. The ruling nations of the successor states also had to undergo a significant part of these painful changes, and the difficult conditions of the Hungarian minorities living in these countries were compounded by the enforced policy of assimilation, and the legal, spiritual and material discrimination that came with secondrate citizenship.

In the cataclysm of the 20th century, after Trianon we lost 10.6 million fellow countrymen, 30 per cent of whom were native speakers of Hungarian. 7.6 million people remained in the rump state, the ratio of ethnic Hungarians was 88 per cent (the only ethically unified state in the region). As a result of natural growth, their number once again approached 10 million. By peaceful territorial revision the area of the country increased from $93,000 \mathrm{~km}^{2}$ to 172,000 , and the population rose to 15 million, which was lost after the Peace Treaty of Paris (1947). The birth ratio had been 34-35 per 
thousand until 1914, which had been steadily decreasing since the Treaty of Trianon (5.28), and it has been a negative figure since 1981; in recent years the fertility rate has been 1.34 children, lower than the mortality rate. Since then the population of the country has steadily decreased. Since the World War I, 300-500,000 people have fled from the successor states to the rump. Acting on the Beneš decrees enacted after the World War II, 60,000 ethnic Hungarians were relocated from Slovakia. The number of Slovaks who chose repatriation was lower. Several tens of thousands of Hungarians of German extraction, most of them assimilated, were deported, and Szekler refugees from Romania took their place. Tens of thousands of ethnic Hungarians in Transylvania returned to the mother country first illegally, then legally. The number of ethnic Hungarians living in the successor states (3 million) had decreased to 2.4 million by 2001 (Table 4). This trend continues. Since in 1939 Horthy did not permit the Wehrmacht to march across Hungary despite the most emphatic request of Hitler, hundreds of thousands of Jews and Poles who found themselves in Nazi and Bolshevik pincers fled to Hungary across the common border. Prosecuted Jews also fled from other European countries, mainly after the accession of Austria to Germany.

The military losses of the World War I and II were 1 million persons each. These figures included two genocides. During the Holocaust several hundred thousand fellow Hungarians were deported to extermination camps, in addition to the Jews, members of the resistance movement (including the son of the Governor) and a few thousand Roma. In the Novi Sad raid of 1942 Hungarian combatants executed about 3500 people, while at the end of 1944 and the beginning of 1945 the partisans of Tito massacred about 35-40,000 Hungarian civilians. The fascists of Slovakia and the Maniu Guard in Romania killed a few thousand people, but the number of ethnic Hungarians who emigrated from the hinterlands is unknown. We lost about 200,000 ethnic Hungarians in Soviet war captivity for various causes. The purges after 1945 took the lives of about 30,000 people, but the number of people who fell in the freedom fight of 1956 and in the retaliation is lower than that. For the last one hundred years emigration has exceeded immigration. After the era of the Hungarian Soviet Republic only a few hundred Bolsheviks fled the country, and a few thousand persons left owing to the spread of fascism and the strengthening of the Nazis before and during the World War II. Between 1945 and 1948 several hundred thousand people emigrated from Hungary, and after 1956 over 200,000 people left the country. The most educated, cultured and wealthy groups in society fled the country (including 3000 university lecturers).

At the end of the 19th century (antisepsis - Ignác Semmelweis, asepsis - Lister, vaccines) and in the first half of the 20th century (discovery of bacteria, increasingly efficient medications) epidemics caused by bacteria were terminated, but epidemics caused by viruses were not. The Spanish flu swept over Europe in three large waves and substantially affected Hungary as well. The virus infections of recent decades (AIDS, West Nile fever, Ebola etc.) and the danger of already terminated epidemics flaring up again can be associated with global tourism, migration towards Europe and "sexual liberation." 
The ethnic Hungarian communities of the successor states were also inflicted by enforced assimilation. One million ethnic Hungarians disappeared because they rejected their ethnic identity. The destination of emigration caused by discrimination was mainly Hungary at first, then in the last decade the countries of Western Europe (Figure 2).

Figure 2: Changes in the number of ethnic Hungarians between 1910 and 1990, according to census figures

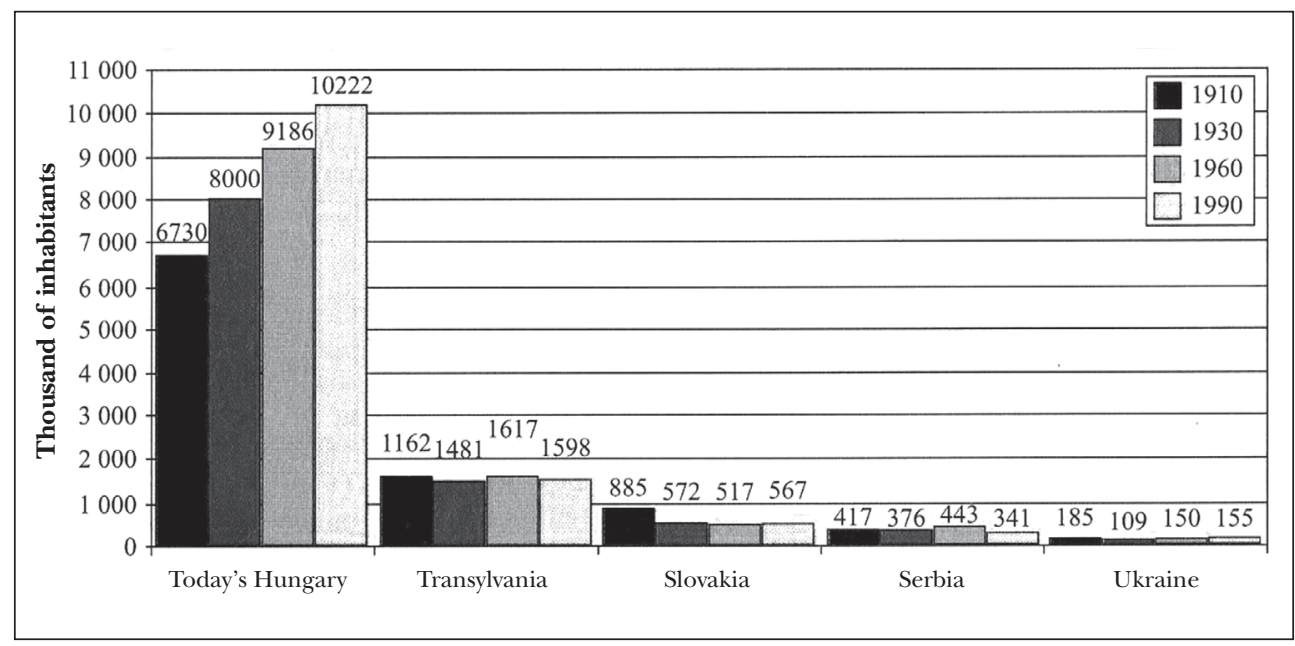

Source: Ember-Molnár-Varga, 2009

At the end of the World War II the prohibition on abortion was suspended because the Soviet Army raped several hundred thousand women, from teenagers to old women. The aggressive syphilis epidemics of the Middle Ages avoided the country - in the 19th and 20th centuries it was sporadic and mainly affected bohemian circles -, but in 1945 480,000 doses of Salvarsan handed out. In order to create more cannon fodder for the next world war, the communists introduced an extremely stringent prohibition on abortion. In the era named after Bolshevik minister Anna Ratkó, natural growth increased significantly and, furthermore, the children and grandchildren of the children born in that era also increase the number of births while they are of child-bearing age. After the laws on abortion were slightly liberalized in the Soviet Union in 1955, all restrictions were totally lifted in Hungary, which is unique in the entire world. As a result, to this day 6 million abortions have been performed, thereby causing one of the worst demographic disasters of the Hungarian nation. If it had not been so, there would be over 20 million ethnic Hungarians in total (Für, 2001).

Summary: having been spontaneously formed from populations of various ethnicities, the Hungarian nation created a special legal system and state organization, society and culture over a period of 600 years, as a sovereign and complete medium-sized power, acknowledging the sacredness of the kings of the Árpád House, then the traditions and cohesive power of the Doctrine of the Holy Crown. This natural development 
was arrested for half a century by the Mongolian invasion, the attack of a world power that was alien in every respect and to which the Kingdom of Hungary offered armed resistance, which resulted in the extermination of about 30 per cent of the population, while the ethnic composition of the country did not change. In the 300 year-long war against another foreign world power, the Ottoman Empire, the national was bled dry, its sovereignty and integrity were impaired, and the number of ethnic Hungarian inhabitants fell from 4 million to one-third of this figure. After the Ottomans had been driven out, the fact that the Habsburg emperor was the King of Hungary ensured the territorial integrity of the country, the constitutionality of it being separate from the rest of the empire, and its sovereignty tied to the interests of the empire; the violation of this sovereignty was restored after two wars of independence (1703-1711, 18481849), first by a peace treaty, and then by conciliation. The two-thirds of the population lost during the wars against the Ottomans was replaced by refugees and immigrants who came of their own accord and often received support, but the ethnic ratios did not reach their original level, although they did improve. After the end of the AustroHungarian Monarchy, Hungary was torn up into seven parts and two-thirds of the area of the country was taken away under the terms of the Treaty of Trianon, which could not be justified by any set of arguments. Over half of the inhabitants of the country, 54 per cent of them ethnic Hungarians, were forced to become citizens of foreign countries; this covered 30 per cent of the entire community of ethnic Hungarians.

For 1000 years Hungary defended Europe (the "Schengen borders") based on systems of ideals through the changing historical eras. Owing to its laws, traditions and ideals, it welcomed all refugees and immigrants without any kind of discrimination, most of whom were integrated into Hungarian conditions. The majority of these people assimilated spontaneously and fully (Pechenegs, Cumans, Jász, Italians, Poles, Bunjevci, Swabians, Saxons, Armenians and minor ethnic groups), while others only assimilated only partially (Serbs, Slovaks, Jews, Wends). Some of them referred to themselves as Hungarians (Ruthenians and Roma).

Integration was voluntary, and assimilation took place spontaneously. Practically there were no efforts at forced assimilation. Some of those refugees and immigrants who lived in blocks and accepted the Hungarian state regime developed a parallel national identity owing to nationalism emerging in the 19th century, and different religious affiliations under the influence of religious and secular leaders; they did not assimilate and provided an excuse and argument for splitting up the one-thousandyear old country, whether or not the majority approved of that. They were assigned to artificially-created or enlarged states that did not prove viable. Having been forced into the successor states, the ethnic Hungarians could not even exercise the rights sanctioned by the Treaty of Trianon. They did not assimilate, despite many kinds of powerful violence and coercion. The community of Hungarian immigrants in the West was partially assimilated, and partially it has a dual identity, maintaining the awareness of its origins, sometimes for several generations.

Despite wars, waves of emigration and the liberal abortion law, during 1100 years the community of ethnic Hungarians has multiplied: from a people of a few hundred 
thousand it turned into a nation of fifteen million. Despite the coercions after the Treaty of Trianon, it has grown by fifty per cent - across seven countries - over the last one hundred years, and still remains the largest population in the Carpathian basin, a perfect geo-economic and political unit (13-15 million), with immigrant communities in the Americas, in Western Europe and in Australia totalling millions.

This is why we are optimists.

\section{REFERENGES}

Ádám, Magda (1989): A kisantant és Európa 1920-1929 [The Little Entente and Europe, 1920-1929]. Akadémiai Kiadó, Budapest.

Anonymus - Kézai, Simon (2004): A magyarok cselekedetei [Deeds of the Hungarians]. Osiris Kiadó, Budapest.

Bálint, István János (ed.) 1999: Kézai Simon Magyar krónikája [Simon Kézai’s Hungarian Chronicle]. Magyar Ház, Budapest, 11-17.

Bandholtz, Harry Hill (1993): Román megszállás Magyarországon. Napló nem diplomata módra [Romanian Occupation in Hungary. An Undiplomatic Diary]. Magyar Világ, Budapest.

Bárány, Attila (2010): Zsigmond király, a konstanzi zsinat és a százéves háború [King Sigismund, the Council of Constance and the Hundred Years' War]. Századok, no. 6, 1345-1396.

Barta, Gábor (1979): Az Erdélyi Fejedelemség születése [The Birth of the Principality of Transylvania]. Gondolat Kiadó, Budapest.

Békés, Csaba (2006): Az 1956-os magyar forradalom a világpolitikában [The 1956 Hungarian Revolution in World Politics]. 1956-os Intézet, Budapest.

Bencsik, Gábor (2002): Igazságot Magyarországnak. Lord Rothermere és a magyar revízió [Justice to Hungary! Lord Rothermere and the Hungarian Revision]. Magyar Mercurius, Budapest.

Benda, Kálmán (ed.) (1980): Európa és a Rákóczi-szabadságharc [Europe and Rákóczi’s War of Independence]. Akadémiai Kiadó, Budapest.

Bertényi, Iván (1987): Magyarország az Anjouk korában [Hungary During the Anjou]. Gondolat Kiadó, Budapest.

Bonfini, Antonio (2005): A magyar történelem tizedei [Decades of Hungarian History]. Ed. Katalin S. Varga, Balassi Kiadó, Budapest.

Brodarics, István (2003): Igaz leírás a magyaroknak a törökökkel Mohácsnál vívott csatájáról [A True Description of the Hungarians' Battle with the Turks at Mohács]. http://mek.oszk.hu/05800/05872/html (accessed 8 February 2015).

C. Tóth, Norbert (2009): Luxemburgi Zsigmond uralkodása 1387-1437 [The Reign of Sigismund of Luxembourg, 1387-1437]. Kossuth Kiadó, Budapest.

Canning, Joseph (2002): A középkori politikai gondolkodás története 300-1450 [History of Medieval Political Thinking, 300-1450]. Osiris Kiadó, Budapest.

Cartwright, Frederick F. - Biddiss, Michael (2000): Disease and History. Stroud, Sutton.

Cliff, Andrew - Haggett, Peter - Smallman-Raynor, Matthew (2004): World Atlas of Epidemic Diseases. Oxford University Press, New York.

Constantine Porphyrogenitus (2003): A birodalom kormányzása [On the Governance of the Empire]. Lectum, Szeged, 98-100, 101-103.

Corpus Juris Hungarici. Magyar Törvénytár 1000-1525. [Hungarian Law Library] Selection. http://mek.oszk. hu/01300/01396/ (accessed 27 August 2014).

Dedinová, Sidonia (2004): Benes, a likvidátor [Benes, the Liquidator]. Korona Kiadó, Budapest.

Dümmerth, Dezsó (1982): Az Anjou-ház nyomában [In Search of the Anjou Dynasty]. Panoráma, Budapest.

Dümmerth, Dezsô (1996): Az Árpádok nyomában [In Search of the Árpáds]. Junior, Budapest, 26-36.

Ember, István (ed.) (2007): Történeti tan [History]. Dialóg Campus Kiadó, Pécs-Passau-Budapest.

Ember, István - Molnár, F. Tamás - Varga, Csaba (eds.) (2009): Történeti egészségtan (Historical Health]. Dialóg Campus Kiadó, Budapest. 
Fischer-Fabian, Siegfried (1985): A német cézárok. A középkor császárainak tündöklése és bukása. Európa Kiadó, Budapest, 15-95.

Freising, Otto of (1913): I. Frigyes császár tettei [The Deeds of Emperor Frederik I]. Athenaeum Rt., Budapest. Für, Lajos (2001): Magyar sors a Kárpát-medencében. Népesedésünk évszázadai 896-2000 [Hungarian Fate in the Carpathian Basin. Centuries of Our Demography, 896-2000]. Kairosz Kiadó, Budapest.

Gergely, András (ed.) (2005): Magyarország története a 19. században [Hungary's History in the 19th Century]. Osiris Kiadó, Budapest.

Görgey, Artúr (2004): Életem és múködésem Magyarországon 1848-ban és 1849-ben [My Life and Activities in Hungary in 1848 and 1849]. http://mek.oszk.hu/04700/04739/html/index.htm (accessed 9 September 2015).

Gulyás, László (2012): A Horthy-korszak külpolitikája [Foreign Policy During the Horthy Regime]. Attraktor Kiadó, Máriabesnyő-Gödöllő.

Györffy György (2000): István király és mûve [King Stephen and His Work]. Balassi Kiadó, Budapest.

Györffy, György (ed.) (2002): A magyarok elődeirôl és a honfoglalásról [About the Ancestors of Hungarians and About the Conquest]. Osiris Kiadó, Budapest.

Havas, László (ed.) (2005): Sancti Stephani regis primi Hungariae. Libellus de institutione Morum sive Admonitio spiritualis. Szent István: Erkölcstanító könyvecske avagy intelmek [Saint Stephen: A Booklet of Ethics or Instructions]. University of Debrecen, Debrecen.

Hermann, Róbert - Závodszky, Géza (1999): Nemzet születik [A Nation Is Born]. Helikon Kiadó, Budapest.

Hermann, Róbert (2001): 1848-1849. A szabadságharc hadtörténete [1848-1849. History of the War of Independence]. Korona Kiadó, Budapest.

Hermann, Róbert (2009): I. Ferenc József és a megtorlás [Franz Joseph I and the Retaliation]. Új Mandátum Kiadó, Budapest.

Hóman Bálint - Szekfú Gyula (1936): Magyar történet [Hungarian History]. Királyi Magyar Egyetemi Nyomda, Budapest.

Horthy, Miklós (2011): Emlékirataim [Memoires]. Európa Kiadó, Budapest.

Huszár, Tibor (2003): Kádár János politikai életrajza [A Political Biography of János Kádár]. Kossuth Kiadó, Budapest.

Kállay, Miklós (2012): Magyarország miniszterelnöke voltam I-II. [I Was Hungary’s Prime Minister I-II]. Európa Kiadó, Budapest.

Katona, Tamás (ed.) (1979): A korona kilenc évszázada. Történelmi források a magyar koronáról [Nine Hundred Years of the Crown. Historical Sources About the Hungarian Crown]. Európa Kiadó, Budapest, $296-359$.

Klinger, András (1997): Magyarország népessége a népszámlálások alapján [Hungary’s Population On the Basis of Sensuses]. In: Historical demography of Hungary 896-1995. Millecentennial lectures. Ed. József Kovacsics, KSH, Budapest, 295-317.

Kovacsics, József (ed.) (1997): Magyarország történeti demográfíja 896-1995 [Hungary’s Historical Demography 896-1995]. KSH, Budapest.

Kövér, György - Gyáni, Gábor (2006): Magyarország társadalomtörténete a reformkortól a második világháborúig [Hungary's Social History Between the Age of Reforms and World War II]. Osiris Kiadó, Budapest.

Kristó Gyula (ed.) (1995): A honfoglalás korának irott forrásai [Written Sources from the Age of the Conquest]. Szegedi Középkorász Múhely [Medieval Workshop of Szeged], Szeged.

Lackó, Mihály (1977): Széchenyi és Kossuth vitája [The Debate Between Széchenyi and Kossuth]. Gondolat Kiadó, Budapest.

László, Gyula (1970): A „kettôs honfoglalás”-ról [About the Double Conquest]. Archaeológiai Értesitô, vol. 97, no. 2, 160-190.

László, Gyula (1988): Árpád népe [Árpád's People]. Helikon Kiadó, Budapest, 132-133.

M. Kiss, Sándor - Raffay, Ernố - Salamon, Konrád (2011): Magyarország sorstragédiái a 20. században [Hungary's Tragedies in the 20th Century]. Éghajlat Kiadó, Budapest.

Marczali, Henrik (1997): Mária Terézia és kora [Empress Maria Theresia and Her Age]. Laude Kiadó, Budapest.

Matuz, József (1990): Az Oszmán Birodalom története [History of the Ottoman Empire]. Akadémiai Kiadó, Budapest. 


\section{Civic Review · Vol. 13, Special Issue, 2017}

Montgomery, John Flournoy (2004): Magyarország, a vonakodó csatlós [Hungary, the Reluctant Surrogate]. Zrínyi Kiadó, Budapest.

Nyárády, R. Károly (1997): Erdély népességének etnikai és vallási tagolódása a magyar államalapítástól a dualizmus koráig [The Ethnic and Religious Composition of The Population of Transylvania Between the Foundation of the State and the Age of Dualism]. Erdélyi Múzeum, vol. 59, no. 1-2, 1-39.

Pálosfalvi, Tamás (2005): Nikápolytól Mohácsig 1396-1526 [From Nicopolis to Mohács]. Zrínyi Kiadó, Budapest. Pálosfalvi, Tamás (2009): A Hunyadiak kora 1437-1490 [The Age of the Hunyadis]. Kossuth Kiadó, Budapest. Püski, Levente (2010): A Horthy-korszak 1920-1941 [The Horthy Era, 1920-1941]. Kossuth Kiadó, Budapest.

R. Várkonyi, Ágnes (1999): A Királyi Magyarország 1541-1686 [Royal Hungary, 1541-1686]. Vince Kiadó, Budapest.

Rákosi, Mátyás (1997): Visszaemlékezések 1940-1956 II. [Recollections, 1940-1956 II]. Napvilág Kiadó, Budapest. Renan, Ernest (1994): Mi a nemzet? Holmi, no. 8, 1177-1188.

Romsics, Ignác (2005): A trianoni békeszerzôdés [The Trianon Treaty]. Osiris Kiadó, Budapest.

Sallai, Gergely (2002): Az elsố bécsi döntés [The First Vienna Decision]. Osiris Kiadó, Budapest.

Shirer, William L. (1996): A Harmadik Birodalom felemelkedése és bukása. A náci Németország története [The Rise and Fall of the Third Reich. A History of Nazi Germany]. Teleteacher, Budapest.

Szabados, György (2010): A magyarok bejövetelének hadtörténeti szempontú újraértékelése [Reassessment of the Hungarian Conquest From a Military Historical Perspective]. Hadtörténelmi Közlemények, no. 1-2, 215-235.

Szabados, György (2011): Magyar államalapitások a IX-XI. században [Hungarian State Foundations in the IX-XI Centuries]. Szegedi Középkorász Múhely [Medieval Workshop of Szeged], Szeged.

Szabó, Béla (2013): A magyar korona országainak statusjogi és monarchiai állása a pragmatica sanctio szerint [The Legal Status and Monarchical Status of the Countries Under the Hungarian Crown According to the Pragmatica Sanctio]. Históriaantik Könyvesház, Budapest.

Szakály, Ferenc (1979): Honkeresôk. Megjegyzések Cserni Jován hadáról [Home Seekers. Notes on the Army of Jovan Cherny]. Történelmi Szemle, no. 2, 227-261.

Szakály, Ferenc (1986): Hungaria eliberata. Budavár visszavétele és Magyarország felszabadítása a török uralom alól 1683-1718 [Hungaria Eliberata. The Recapture of Buda and Hungary's Liberation from Turkish Rule 1683-1718]. Corvina Kiadó, Budapest.

Szamosközy, István (1981): Erdély története 1598-1599, 1603 [History of Transylvania, 1598-1599, 1603]. Európa Kiadó, Budapest.

Szerémi, György (1979): Magyarország romlásáról [About Hungary’s Decline]. Szépirodalmi Kiadó, Budapest.

Tamás, Edit (ed. (2003): A Rákóczi-szabadságharc és Közép-Európa I-II [Rákóczi's War of Independence and Central Europe I-II]. Sárospataki Rákóczi Múzeum, Sárospatak.

Tarján,Tamás (ed.) (1993): Képes Krónika. A magyarok a régi és legújabb tetteirôl, eredetükrôl és növekedésükrôl, diadalaikról és bátorságukról [Illuminated Manuscript. About the Former and Most Recent Deeds of the Hungarians, Their Origins and Increase, Victories and Courage]. Magyar Hírlap - Maecenas Kiadó, Budapest, 24-26.

Thaly, Kálmán (ed.) (1872): II. Rákóczi Ferencz emlékiratai [The Memoires of Ferencz Rákóczi II]. Ráth Mór, Pest.

Tóth, Zoltán József (2007): Megmaradásunk alkotmánya. A Szent Korona-eszme a magyar történelemben és közjogban [The Constitution of Our Survival. The Concept of the Holy Crown in Hungarian History and Public Law]. HUN-idea, Budapest.

Veszprémy, László (2008): Az Árpád-és Anjou-kor csatái, hadjáratai [Battles and Campaigns During the Árpáds and the Anjou]. Zrínyi Kiadó, Budapest.

Veszprémy, László (ed.) (2002): Szent István és az államalapítás [Saint Stephen and the Foundation of the State]. Osiris Kiadó, Budapest.

Zeidler, Miklós (ed.) (2008): Trianon. Osiris Kiadó, Budapest.

Zsoldos, Attila (2015): Az Árpádok és asszonyaik. A királynéi intézmény az Árpádok korában [The Árpáds and Their Ladies. The Institution of the Queen Consort in the Age of the Árpáds]. MTA Történettudományi Intézet [MTA Institute of History], Budapest. 